\title{
Esthetics and function: a return to the basic concepts: case report
}

\author{
Estética e função: um retorno aos conceitos básicos: caso clínico
}

Camille Sá Nogueira FROTA ${ }^{1}$

Wagner Araújo de NEGREIROS²

Ana Cristina de Mello FIALLOS 2

Romulo Rocha REGIS²

\begin{abstract}
Immediate esthetic rehabilitation is a common practice in contemporary restorative dentistry. Sometimes without a precise diagnosis and clinical planning, two or three clinical sessions have been sufficient to start and end an extensive all-ceramic oral rehabilitation. It is essential, however, for these treatments to be based on the biological, mechanical, and occlusal principles that have been established for decades, and not only on aesthetic considerations. In this case report, a 26 year-old bruxist patient with functional and aesthetic needs, was rehabilitated with ceramic restorations in the six maxillary anterior teeth, through an interdisciplinary approach. The diagnostic wax-up was essential to predict the outcome; guide the periodontal surgery; serve as a reference for dental preparations, and restore the dynamics of jaw movements. After the adhesive cementation, a protective occlusal splint for use during sleep was introduced. The authors concluded that careful diagnosis and planning was critical to outcome of this case, and that the quality and longevity of restorative treatment depended on the respect for biomechanical, occlusal, and aesthetic concepts.
\end{abstract}

Indexing terms: Ceramics. Dental prosthesis. Esthetics. Mouth rehabilitation.

\section{RESUMO}

Reabilitações estéticas imediatas são práticas frequentes na Odontologia restauradora atual. Por vezes, sem um diagnóstico e um planejamento clínico preciso, duas ou três sessões clínicas têm sido o bastante para iniciar e finalizar uma reabilitação oral extensa totalmente cerâmica. Contudo é fundamental que esses tratamentos voltem a ser sustentados por princípios biológicos, mecânicos e oclusais básicos, instituídos há décadas, e não apenas por aspectos estéticos. No presente relato de caso, uma paciente de 26 anos, bruxista, com necessidades funcionais e estéticas, foi reabilitada com restaurações cerâmicas nos 6 dentes anteriores superiores, por meio de uma abordagem interdisciplinar. O enceramento diagnóstico realizado foi fundamental para prever o resultado, guiar a cirurgia periodontal, servir de referência para os preparos dentais e restaurar a dinâmica dos movimentos mandibulares. Após a cimentação final das restaurações, a proteção com placa oclusal no período do sono foi instituída. Concluiu-se que um criterioso diagnóstico e planejamento foi fundamental para o desfecho do caso, e que a qualidade e a longevidade desse tratamento restaurador parece depender intimamente do respeito aos conceitos biomecânicos, oclusais e estéticos.

Termos de indexação: Reabilitação bucal. Estética. Prótese dentária. Cerâmica.

\section{INTRODUCTION}

The specialty of Prosthetic Dentistry must return to placing value on the teaching of basic concepts in all the sub-areas ${ }^{1}$. Clinical planning must always be guided by a coherent sequence of data collection: anamnesis, medical and dental history, clinical and complementary exams, and a precise diagnosis ${ }^{2}$. The treatment plan must meet the requirements of the chief complaint, resolve the emergency situation, analyze the oral health status, adjust the oral environment and perform the rehabilitation itself ${ }^{2-4}$. New diagnostic tools, such as photography, virtual planning and mock-up simulations should be added to the treatment as additional possibilities of explaining doubts, and indicate the esthetic predictability of the case $\mathrm{e}^{5-6}$. Unfortunately, nowadays an avid concern is observed about transforming smiles in a short space of time, "skipping" relevant stages by means of superficial diagnosis and planning in certain

\footnotetext{
${ }^{1}$ Universidade Federal do Ceará, Curso de Odontologia. Fortaleza, CE, Brasil.

2 Universidade Federal do Ceará, Curso de Odontologia, Departamento de Odontologia Restauradora. Rua Monsenhor Furtado, s/n., Rodolfo Teófilo, 60430-350, Fortaleza, CE, Brasil. Correspondência para / Correspondence to: WA NEGREIROS. E-mail: <wagnerufc@yahoo.com.br>.
} 
clinical situations. In effect, the outcome of a successful restorative therapy appears to be most dependent on an adequate clinical diagnosis and careful procedural steps right from preparation, temporary restorations, impression taking through to the final cementation.

Respect for the biomechanical principles must be a fundamental aspect throughout the entire restorative treatment. Some clinical and decisionmaking considerations must guide the therapy: thickness of tooth tissue removed (enamel or dentin), level of wear (supragingival or intrasulcular), substrate shade, maintenance of pulp vitality, use of intraradicular retainers, crown/root proportion, type of restorative material, type of cement, method of fabricating ceramic restorations, occlusal pattern, and parafunctional habits ${ }^{7-13}$. In view of the foregoing, the aim of the present study was to present a moderately complex clinical case, treated by integrating the areas of periodontology, endodontics and prosthodontics, emphasizing the importance of knowledge about the biological, mechanical, occlusal and esthetic principles that govern oral rehabilitation.

\section{CASE REPORT}

The patient a 26-year-old woman, university student, without systemic changes, presented to the Dental Prosthesis Clinic of the Federal University of Ceará (UFC) with the chief complaint of dissatisfaction with the accentuated wear of her maxillary anterior teeth and difficulties with chewing (Figures $1 \mathrm{~A}$ and $1 \mathrm{~B}$ ). During anamnesis, the patient was unable to report the reason why, or when the loss of tooth substance began, and was anxious to obtain teeth with a natural appearance. In the clinical exam, her smile and face were analyzed from various angles, and a set of high quality photographs and videos were obtained. The periodontal health of the teeth and adequate biofilm control were verified. The patients signed a term of free and informed consent considering spontaneous adhesion to the treatment, and agreeing to photographic documentation and the possibility of scientific publication of the therapy. Subsequently, impressions were taken with condensation silicone (Speedex, Coltene, Switzerland) of the dental arches, and mounting the study model in a semi-adjustable articulator (Articulador 4000S, Bio-art, Brazil) (Figures 2A and 2B). Considering the aspects of golden proportion, facial lines and planes, and the principles of oral and occlusal esthetics, diagnostic wax-up was performed on the study model. By means of a matrix made of condensation silicone, and intraoral diagnostic mock-up was created with bisacrylic resin in shade A2 (Protemp 4, 3M ESPE, USA), after obtaining the patient's consent to have the treatment performed (Figure $3 \mathrm{~A})$. The mock-up would provide the guidance necessary for fabrication of the dental preparations for the ceramic restorations (Figure 3B).

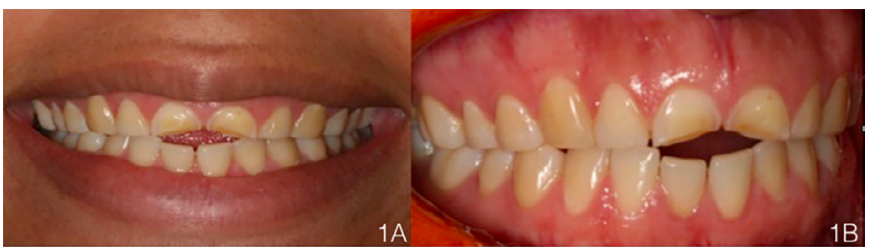

Figure 1. A) Initial view of the smile; Figure 1B) Initial intraoral view.

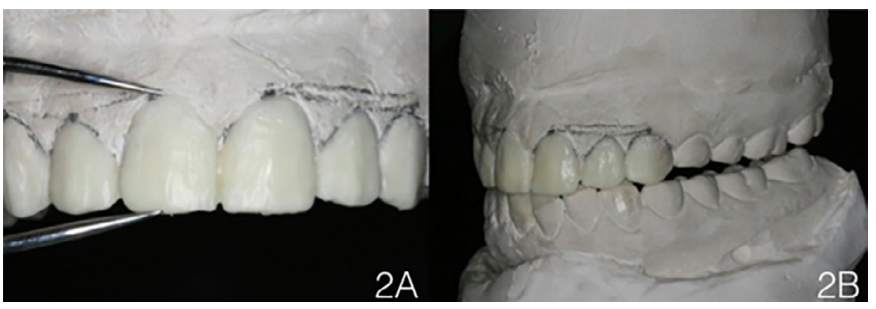

Figure 2. A) Diagnostic Wax-up, observing height/width proportion; Figure 2B) Mandibular movements visualized in the articulator.

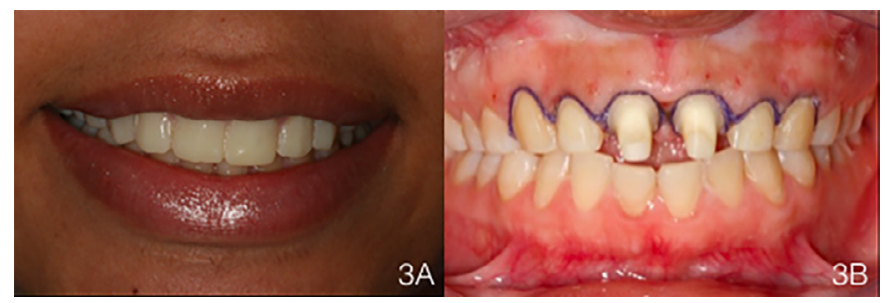

Figure 3. A) Mock-up; Figure 3B) Dental preparations (with retractor wire) guided by the wax-up/mock-up.

Considering the reliability of the diagnostic wax-up, the authors perceived the need for endodontic treatment of teeth 11 and 21 for prosthetic purposes, to augment the height/width proportion of the preparations. Thus, glass fiber posts (Reforpost, Angelus, Brazil) and a filling core with resin composite (Filtek Z350, 3M ESPE, USA) were used. Subsequently, the temporary restorations were performed with resin composite, taking care to maintain an adequate emergence profile, with the purpose of favoring healing of the periodontal surgery to be performed. Furthermore, with the goal of balancing the 
levels of the gingival zeniths, surgery was performed for esthetic clinical crown augmentation involving teeth 11 and 21; and superior frenectomy, using as reference, an acetate surgical guide (Placa Cristal de Acetato, Bio-art, Brazil) thermoplasticized under vacuum, on the duplicate wax-up model (Figures 4A and 4B).

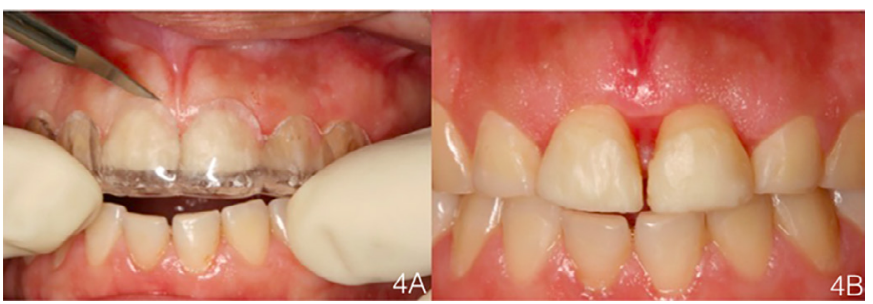

Figure 4. A) Clinical crown augmentation surgery using the acetate matrix as reference; B) Post-surgical period after 20 days.

When 60 days had elapsed after the periodontal surgery performed, fabrication of the prosthetic preparations began for the total metal-free crowns on teeth 11 and 21; and for indirect laminated facets with reduced thickness on teeth $12,13,22$ and 23 with cervical terminal at the gingival level, since the dental substrate shade had been maintained. To guide fabrication of the preparations, a new matrix made of condensation silicone (Speedex, Coltene, Switzerland) was obtained from the diagnostic wax-up. Impressions of the work were then taken with addition silicone (Adsil, Coltene, Switzerland) and gingival tissue retraction performed with double retractor cord (Ultrapack, Ultradent, USA), in addition to obtaining a plaster cast with Type IV plaster (Durone IV, Dentsply, USA). On conclusion of the laboratory stage of obtaining the made-up, pressed ceramic restorations, ingots LT (low translucence) in shade A2 (E-max, Ivoclar Vivadent, Liechtenstein), a new clinical dry and humid tryin was performed with minimal proximal adjustments. With the patient's approval and selection of the cement shade with try-in pastes (shade mean value or 0 ), the careful stage of cementation and occlusal adjustment of the restorations followed (Figures 5A and 5B); with the use of resin cement (Variolink venner, Ivoclar Vivadent AG, Leichtenstein), preceded by due tooth and ceramic surface treatment in accordance with the manufacturer's instructions. During the return consultations, the authors performed slight clinical adjustments (esthetic and functional) and instructed the patient about oral hygiene and maintenance, in addition to indicating the use of a maxillary occlusal plate made of acrylic, with total coverage, for use during periods of sleep (Figures $6 \mathrm{~A}$ and $6 \mathrm{~B}$ ). The patient has been under observation for a period of 2 years, demonstrating normal masticatory function, oral comfort and a preserved esthetic appearance.

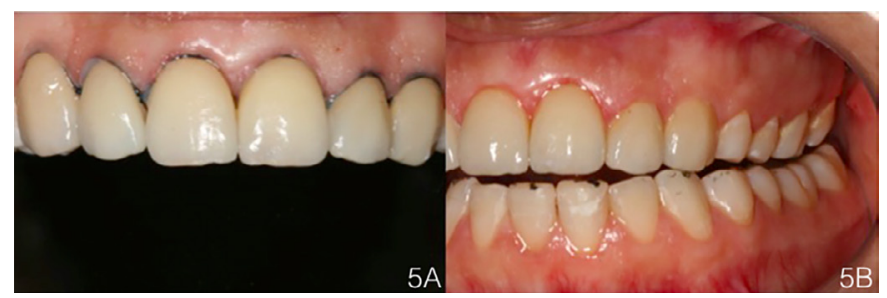

Figure 5. A) Selection of cement shade with try-in pastes; B) Clinical adjustment of the canine guide after cementation.

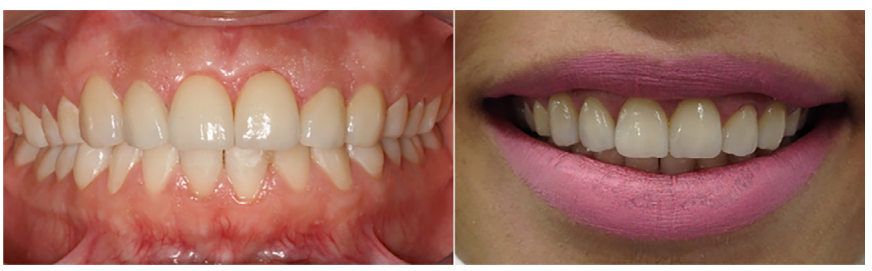

Figure 6. A) Final intraoral condition; B) Final view of the smile.

\section{DISCUSSION}

Interdisciplinary action is a preponderant factor when faced with therapies that have direct impact on oral functions, and oral and facial esthetics ${ }^{14}$. Mounting the plaster casts in a semi-adjustable articulator was important in conducting the clinical situation here described. The facial arch was necessary for determining the inclination of the occlusal plane in view of the severe wear of the teeth, since rehabilitation involved the anterior segment of the mouth. The articulator also allowed the fabrication of a diagnostic wax-up considering the centric and eccentric movements of the mandible, with restoration of the anterior guide by the incisors and lateral guide by the canines, fundamental for a mutually protected occlusal pattern ${ }^{15}$. The dental anatomy was re-established according to the concepts of the golden proportion, facial lines and planes and the principles of oral esthetics $^{16}$. Use of the diagnostic mock-up tool is always important in esthetic work in the anterior segments of the mouth, to the extent to which the following concepts are 
analyzed: labial support, incisal height, gingival zeniths, gingival and incisal crenations, proximal contacts, smile line, buccal corridor, shape of the incisors and face, color, phonetic aspects, oral and facial esthetics ${ }^{5-6}$.

It would seem obvious that attempts must be made to preserve the health and vitality of the pulp organ $^{3}$, however, in the present clinical case, endodontic treatment of teeth 11 and 12 was indicated for prosthetic purposes, so that there would be an increase in the height/ width proportion of the dental preparations. Glass fiber posts were indicated because they have a modulus of elasticity close to that of the dental remainder, as they satisfactorily distribute the forces exerted on the tooth structure to reduce the risk of fracture, in addition to being esthetic ${ }^{17-19}$. The dental preparation must contemplate fundamental mechanical principles (retention, resistance to displacement or stability, structural rigidity and marginal integrity), in spite of the large increase in retention and strength of the restoration promoted by the bond strength to enamel20-22. The reduction of tooth tissue for total crowns must demand minimal thickness to support the ceramic material, with adequate expulsion and rounded angles, and with limits in tooth enamel. For laminated ceramic facets, attention must be paid to slight chamfering of the cervical terminal demarcation and slight rupture of the proximal contact with abrasive papers ${ }^{3}$. It is important to emphasize the extensive preservation of healthy tissue when a silicone matrix is used, based on the diagnostic wax-up to guide fabrication of the preparations. In the clinical case under study, the teeth restored with laminated facets were healthy, which allowed complete bonding to tooth enamel.

An increase in the esthetic clinical crown was important for aligning the gingival zeniths, with maintenance of integrity of the biologic space, fundamental for the junctional epithelium and connective tissue attachment to the tooth structure ${ }^{23}$. Moreover, indirect ceramic restorations must maintain an adequate emergence profile to reduce biofilm accumulation and contribute to periodontal health ${ }^{24}$. When the biologic space is violated there is an inflammatory response, resulting in transitory or permanent changes in the supporting periodontium ${ }^{11,24}$. Furthermore, balance of the level of the central incisor zeniths with those of the canines, leaving the zenith of the lateral incisors $1 \mathrm{~mm}$ below those, provided a more adequate esthetic condition, in alignment with the principles of oral esthetics ${ }^{25}$.

The metal-free ceramic systems offer alternative advantages to those of the metal-ceramic types in restorative treatment ${ }^{26}$. They offer better distribution of light reflection, by reason of their high capacity for mimicking the dental tissues $^{27}$. Relative to the cementation method, these may be denominated acid-sensitive and acid-resistant, because they either allow or disallow prior etching with hydrofluoric acid and silanization ${ }^{28-29}$. In this study, an acid-sensitive, made-up, pressed, lithium disilicate-based ceramic was used. By the surface treatment and silanization process, adhesive cementation for this restoration presupposed the obtainment of strong and reliable bond strength to the remaining tooth structure, which allowed better distribution of loads during mastication, diminishing the risk of cementation failure or fracture of the restoration ${ }^{20}$. Adhesive resin cementation also improves the prognosis in case of short or expulsive posts, and partial restorations such as the laminated facet type 22 .

The patient under treatment presented clinical signs of sleep bruxism, also reported by family members. Sleep bruxism is characterized by non-functional contact of the teeth, manifested by grinding or clenching the teeth. It seems to be mediated far more centrally than peripherally, so that procedures of occlusal adjustment of any nature whatever are contraindicated. As yet, there is no causal treatment for sleep bruxism, so that it is important to counsel the patient about measures for control and protection of the dental structures ${ }^{30}$. The occlusal plate promotes greater stability of the articular components, protects the teeth and supporting structures, however, it has no action on the permanent remission of the parafunction ${ }^{11,19}$.

Success of the restorative treatment is determined by means of criteria such as longevity of the dental prosthesis, esthetics, pulp and periodontal health, and patient satisfaction ${ }^{2}$. The low level of scientific evidence arising from a simple clinical case, such as that here related is well recognized. Certainly, randomized and controlled clinical studies with long-term follow-up are the true indicators of the decisions made by clinicians within the clinic relative to restorative treatments.

\section{CONCLUSION}

The present case report presented a satisfactory functional and esthetic result due to the care taken right from the clinical exam through to final cementation. This article sought to represent the need to resort to the basic biological, mechanical, occlusal and esthetic concepts in Prosthodontics in order to perform oral rehabilitations with 
acceptable quality and longevity.

\section{Collaborators}

CSN FROTA was responsible for patients screening, clinical exams, appointments schedule, teeth extractions,

\section{REFERENCES}

1. Hawkinson RT. A prosthodontic wake-up call: reaffirming the complete denture implants alone do not solve the problems: the old principles are still important. J Prosthodont. 2005;14(4):2945. doi: 10.1111/j.1532-849X.2005.00055.x

2. Araújo IC, Araújo MVA, Rocha RG, Perez FEG, Melo CB, Barroso RFF. Planejamento clínico integrado - fase de manutenção da saúde bucal. J Bras Clin Odontol Integr. 2006;10(53):183-7.

3. Pegoraro LF, do Valle AL, Araújo CRP, Bonfante G, Conti PCR, Bonachela W. Prótese fixa. São Paulo: Artes Médicas; 2004.

4. Shillingburg Junior $H T$, Hobo $S$, Whitsett LD, Jacobi R, Brackett SE. Fundamentos de prótese fixa. São Paulo: Quintessence; 1998.

5. Kina S, Bruguera A. Invisível: restaurações estéticas cerâmicas. Maringá: Dental Press; 2007.

6. Cardoso PC, Cardoso LC, Decurcio RA, Monteiro LJE. Restabelecimento estético funcional com laminados cerâmicos. Rev Odontol Bras Central. 2011;20(52):88-93.

7. Bispo BL. Reconstrução de dentes tratados endodonticamente: retentores intrarradiculares. RGO, Rev Gaúch Odontol. 2008;58(1):81-4.

8. Eskitascioglu G, Belli S, Kalkan M. Evaluation of two post core system using two different methods (fracture strength test and a finite elemental stress analysis). J Endod. 2002;28(9):629-33. doi: $10.1097 / 00004770-200209000-00001$

9. Monticelli F, Goracci C, Grandini S, Garcia-Godoy F, Ferrari M. Scanning electron microscopic evaluation of fiber post-resin core units built up with different resin composites. Am J Dent. 2005;18(1):61-5.

10. Nery CF. A Prótese em parceria com a Periodontia. Rev PerioNews. 2009;3(2): 94-9.

11. Almeida LR, Meira ALT, Casarin R, Bittencourt $S$, Ribeiro EDP. Conhecimento de cirurgiões-dentistas e acadêmicos de odontologia sobre o espaço biológico periodontal. Braz J Periodontol. 2011;21(04):66-75.

12. Machado E, Machado P, Cunali PA, Fabro CD. Bruxismo do sono: possibilidades terapêuticas baseadas em evidências. Dent Press J Orthod. 2011;16(2):75-82.

13. Tanaka EE, Arita ES, Shibayama B. Occlusal stabilization appliance. Evaluation of its efficacy in the treatment of temporomandibular disorders. J Appl Oral Sci 2004;12 (3): 6671. doi: 10.1590/S1678-77572004000300015 literature review and article writing. WA Negreiros carried out the prosthodontic procedures. ACM FIALLOS carried out the periodontics procedures. RR REGIS was responsible for the photographs during the clinical appointments and article writing.

14. Ribeiro FV, Negreiros WA de, Panza LHV, Queiroz VS, Consani RLX, Pereira Neto JS, et al. A importância da terapia interdisciplinar na otimização da estética - Relato de caso clínico. Rev PerioNews. 2007;1(4):355-60.

15. Zamperini CA, Franco AL, Faria IR. Avaliação dos contatos oclusais em próteses provisórias unitárias implantossuportadas confeccionadas com e sem arco facial. Rev Cubana Estomatol. 2011;48(2):322-30.

16. Louro RL, Galazi DR, Moscon RM. Proporção áurea no restabelecimento de um sorriso harmonioso. Rev Bras Pesq Saude. 2009;11(2):49-54.

17. Akkayan B, Dent $M$, Gülmez T. Resistence to fracture endodontically treated teeth restored with different post systems. J Prosthet Dent. 2002;87(4):431-7. doi: 10.1067/ mpr.2002.123227

18. Clavijo VGR, Souza CN, Andrade MF, Susin AH. Pinos anatômicos; uma nova perspectiva clínica. Rev Dent Press Estet. 2006:3(3):110-30.

19. Andrade CL, Gonçalves TMSV, Santos IL, Barros MS, Araújo NRR, Cury AADB. Direct adhesive pin-retained restorations for severely worn dentition treatment: a 1.5-year follow-up report. Braz Dent J. 2014;25(4): 357-62.

20. Peixoto LM, Batitucci E, Daroz CBS, Sampaio Filho HR. Tratamento térmico do silano para melhorar a cimentação adesiva de restaurações cerâmicas odontológicas. Cerâmica. 2013;59:460-5.

21. Gürel G, Morimoto S, Calamita MA, Coachman C, Sesma N. Clinical performance of porcelain laminate veneers: outcomes of the aesthetic pre-evaluative temporary (APT) technique. Int J Periodont Res Dent. 2012;32:625-35.

22. Malheiros AS, Fialho FP, Tavarez RRJ. Cerâmicas ácido resistentes: a busca por cimentação resinosa adesiva. Cerâmica. 2013;59(349):124-8.

23. Ferreira Júnior CD, Reis MMGC, Barboza ESP. Recuperação do espaço biológico: uma discussão das medidas utilizadas nas cirurgias de aumento de coroa clínica com osteotomia. RGO, Rev Gaúch Odontol. 2013;61(0):519-22.

24. Reeves WG. Restorative margin placement and periodontal health. J Prosthet Dent. 1991;66(6):733-6. doi: 10.1016/00223913(91)90405-L

25. Frizera F, Fontanari LA, Tonetto MR, Kabbach W, Ottoni J, Masioli MA, et al. Escultura gengival: abordagem cirúrgica em alterações gengivais. Clin Int J Braz Dent. 2012;8(4):388-400.

26. Farias FAR, Feltrin PP, Zanetti AL, Inoue RT. Preparo dentário para coroa metalocerâmica em dentes anteriores por meio da 
técnica de referência Inoue \& Zanetti. RGO, Rev Gaúch Odontol. 2011;59:81-8.

27. Martins LM, Lorenzoni FC, Farias BC, Lopes LDS, Bonfante G, Rubo JH. Comportamento biomecânico das cerâmicas odontológicas: revisão. Cerâmica. 2010;56:148-55.

28. Neis CA, Albuquerque NLG, Albuquerque IS, Gomes EA, Souza Filho $C B$, Feitosa VP, et al. Surface treatments for repair of feldspathic, leucite- and lithium dissilicate - reinforced glass ceramics using composite resin. Braz Dent J. 2015;26(2):152-5.

29. Higashi C, Reggiani RD, Kina S, Scopin O, Hirata R. Cerâmicas em dentes anteriores: parte I - indicações clínicas dos sistemas cerâmicos. Rev Clin. 2009;5(2):55-7.
30. Negreiros WA de, Consani RLX, Mesquita MF, Carvalho BKF de, Pigozzo MN, Bastos PL. Ajuste oclusal para tratamento de disfunção temporomandibular e bruxismo: uma análise crítica. J Bras Oclusão, ATM e Dor Orofacial. 2006; 6(27):95-101.

Received on: 16/7/2016

Final version resubmitted on: 5/10/2016

Approved on: 15/2/2017 